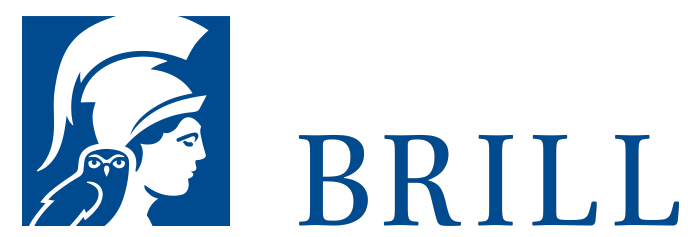

\title{
Papyri selectae
}

Ediderunt Instituti alumni

Authors: P.W. Pestman, Boswinkel, and Sijpesteijn

Pages: $\mathrm{x}, 84$ pp. 1 fold. page, $10[1$ fold.] plates

Language:

English

Subjects:

General,

Classical Studies

Publisher: Brill

Series:

Papyrologica

Lugduno-

Batava, Volume:

13

E-Book (PDF)

Released online:

O2 Mar $202 \mathrm{O}$

ISBN: 978-90-

04-42765-5

List price

USS. \$104.00

Paperback

Publication date: o1 Jun 1965

ISBN: 978-9004-01698-9 
For more information see brill.com

Order information: Order online at brill.com +44330 333 0049 | customerservices@brill.com Submission information: brill.com/authors

Titles published by Brill | Fink, Brill | mentis or Brill | Schöningh: +49(o)715413279216| brill@brocom.de 